\title{
The Interrelationship of FDI and GDP in European Transition Countries
}

\author{
Krešimir Čičak, Petar Sorić \\ Faculty of Economics and Business, University of Zagreb, Zagreb, Croatia \\ Corresponding author (e-mail): psoric@efzg.hr
}

\begin{abstract}
Theory states that the foreign direct investments (FDI) have multiple positive effects on a country's economy. Evidence can be sought from Central and Eastern European countries where FDI is seen as one of the main contributors to GDP growth. This paper examines the relationship between FDI and GDP growth rate in Croatia and other chosen European transition countries using bivariate VAR models. Based on the research conducted, it was found that FDI Granger causes GDP growth in most countries. This is especially true in Poland, Czech Republic and Hungary which have attracted a significant amount of FDI starting from 1990. The estimated VAR models for Latvia and Slovenia provide evidence that GDP causes FDI, corroborating the theory that investor are prone to stable macroeconomic conditions. This paper tries to make a comparative analysis of FDI-GDP link in New EU member states. Further research should certainly include other aspects such as the quality of the legislative system, labor productivity and labor costs, access to capital markets, etc.
\end{abstract}

Key words: FDI, GDP Growth, Granger Causality, VAR

\section{Introduction}

Modern processes of internationalization, globalization and regionalization of economic relations are reflected in progressively freer international movement of capital, especially FDI. A common claim is that any capital, mostly foreign, is highly important and warmly welcomed by countries, especially, if it is in a form of direct investment, for its valuable contribution as a creator new jobs and carrier of new technologies. According to Neuhaus (2005), physical capital accumulation together with technological progress were the main drivers for economic growth over the last decade in several transition countries. The benefits of FDI are also reflected in knowledge and managerial skill transfer as well as increased production and export of 
domestic products and increased competition in the domestic market thanks to contributions of foreign investor.

In the early nineties of the $20^{\text {th }}$ century, European transition countries have started opening their borders, first, to trade in goods and services, and then, to financial flows which sought to modernize their economies in order to create conditions for stronger economic growth in the future. Despite the obstacles in the form of political and economic instability, complex bureaucracy, lack of institutional infrastructure and relatively small markets, foreign investors were attracted by the gravitational factors and low labor costs and FDI had positive effect on the economy of these countries. The purpose of this paper is, therefore, to explore and show that FDI played a significant role in promoting economic growth of selected European transition countries. FDI had a positive effect on employment, domestic production and exports which eventually resulted GDP growth. As structure of this paper concerned, it first provides a review of previous studies. Secondly, methodology and data used in the paper are listed, followed by the results of empirical analysis. Finally some closing thoughts are provided.

\section{Literature review}

In the last twenty years, FDI and its impact on economic growth have been at the center of interest of many scientists. Longitudinal research by Blomström, Lipsey \& Zejan (1992) considering period from 1960 to 1985 shows that FDI causes economic growth, and not vice versa. The results indicate that FDI inflows can encourage GDP growth only in those countries that have crossed a certain threshold of development those which are ready to absorb new technology and use it successfully.

Borensztein, De Gregorio \& Lee (1995) have examined the impact of FDI on economic growth of industrial countries and developing countries for the period from 1979 to 1989 . The results show that the higher the levels of human capital in a country, the more pronounced is the positive impact of FDI on GDP. Namely, human capital is required to accept the technology and ultimately leads to an increase in productivity. Furthermore, FDI has the effect of increasing total investments in a country by more than one-for-one, providing an encouragement for investments. Mencinger (2003) explores the relationship between FDI and economic growth in eight transition countries for the period from 1994 to 2001 . He found FDI to have a negative impact on economic growth. The explanation is that company takeovers have predominated the FDI structure in comparison to greenfield investments. Likewise, cash receipts from the sale of companies during the privatization have been used for consumption and imports, instead of for increasing the productive capital.

Bačić, Račić \& Ahec - Šonje (2004) investigated the impact of FDI on economic growth of eleven transitional countries for the period from 1994 to 2002 . They concluded that FDI has a positive effect on economic growth in small countries like Slovenia, Slovakia and Lithuania and it also has a significant impact on international trade of these countries. However, the impact of FDI on the productivity increase was found as 
a characteristic of more developed countries. Asteriou, Dassiou \& Glycopantis (2005) analyze the impact of FDI on economic growth of ten European transition countries for the period from 1990 to 2003. Their empirical study confirmed the positive correlation between FDI and economic growth, but also a negative correlation between portfolio investments and growth. The results can be explained by the fact that the capital markets are not fully developed in transition countries, while, on the other hand, they are quite attractive for FDI because of the relatively cheap labor force. Katircioglu (2009) empirically examines the relationship level and direction of causality between income from FDI and economic growth in Turkey for the period from 1970 to 2005. Results indicate that the two variables are in a long-term balanced relationship only when FDI is the dependent variable in the context of an autoregressive distributed lag model (ARDL approach. The paper concludes that economic expansion in Turkey stimulates the expansion of FDI net inflows.

Kersan - Škabić \& Zubin (2009) analyze whether FDI inflow has a positive impact on the Croatian economy. According to the obtained results, an impulse in foreign investments decreases only the employment, but not GDP. Therefore it can be concluded that the entry of foreign capital into the country increases the marginal product of labor, and this creates a space for increasing profits, but also, for a long-term increase in real wages. Although the effect of foreign capital now seems negative, it could have a positive impact in the general well-being for the near future. The results can be explained by the fact that most of FDI has arrived in Croatia in large waves of privatization, while there was a shortage of investment in new production. The results indicate the necessity to change the policies of attracting FDI and directing them in sectors with higher added value.

Curwin \& Mahutga (2014), on the other hand, revisit the classic sociological debate on the growth effects of FDI. They conclude that FDI penetration reduces economic growth in the short and long run in post-socialist transition countries. The authors explain their finding by weak institutional environment which allowed foreign capital to overwhelm domestic markets too quickly. There are also papers based on which one can conclude that economic growth encourages FDI inflows. Franc (2008) analyzed the FDI determinants for Croatia and twelve EU members, confirming that, inter alia, the determinants of FDI include lower labor costs, GDP growth rate, labor productivity, foreign trade, legal system and legislation. Mačkić, Škrabić Perić \& Sorić (2014) analyze the systemic competitiveness of post-socialist and capitalist economies. Their research pinpoints several other variables which are relevant to FDI-GDP growth relation such as a country's credit rating, tax evasion, access to capital markets, SMEs, labor regulation flexibility, finance and banking regulation. According to this study, all of the above mentioned variables are relevant competitiveness factors which affect GDP, and might, in turn, have a significant effect on FDI inflows.

The above literature review suggests that FDI by itself cannot positively affect economic growth. The final net effect depends on the level of development of the country itself, the level of human capital, the level of technological development, policies for attracting FDI, etc.

\section{Methodology and data}


The aim of the empirical part of the paper is to use econometric methods and models to examine the relationship between FDI and GDP growth rates in Croatia and selected European transition countries. Several different tests will be used in the research, including the unit root test, the Granger causality test and the bivariate vector autoregressive (VAR) model. ${ }^{1}$

The empirical analysis is carried out on a total of ten European transition countries (Bulgaria, Czech Republic, Estonia, Croatia, Latvia, Lithuania, Hungary, Poland, Romania and Slovenia). It should be noted that the covered time series for each country is different. Quarterly GDP data (in millions of EUR) were obtained from the Eurostat database. After retrieval, data have been seasonally adjusted by the Census X12 method. Finally, log-differencing of data was used to approximate the quarterly growth rates of GDP. The FDI data are taken in the form of the total accumulated value of assets in foreign ownership at the end of each quarter (FDI Stocks, in millions of EUR). These were gathered from the databases of Central Banks of the observed countries. FDI data is also log-differenced, producing quarterly growth rates of FDI (FDI hereinforth).

\section{Results}

\subsection{Stationarity}

In this study the existence of a unit root will be examined using the ADF test (Dickey, Fuller, 1981). The model is specified in a way that it involves both deterministic components, constant and trend yet, if they were not shown to be statistically significant, they were left out from the model.

The ADF test results for the observed time series are given in Table 4-1

\begin{tabular}{|l|l|l|l|}
\hline \multirow{2}{*}{ Country } & Variable & ADF test statistic & $\begin{array}{l}\text { Deterministic } \\
\text { components of the } \\
\text { model }\end{array}$ \\
\hline \multirow{2}{*}{ Bulgaria } & GDP_BG & $-6,369590^{*}(0)$ & Constant, Linear trend \\
\cline { 2 - 4 } & FDI_BG & $-5,963855^{*}(0)$ & Constant, Linear trend \\
\hline \multirow{2}{*}{ Czech Republic } & GDP_CZ & $-5,270181^{*}(1)$ & Constant, Linear trend \\
\cline { 2 - 4 } & FDI_CZ & $-6,329307^{*}(0)$ & Constant, Linear trend \\
\hline \multirow{2}{*}{ Estonia } & GDP_EE & $-2,052781^{* *}(1)$ & - \\
\cline { 2 - 4 } & FDI_EE & $-6,399136^{*}(0)$ & Constant, Linear trend \\
\hline
\end{tabular}

${ }^{1}$ One might raise the question of possible omitted variable bias or endogeneity problem in bivariate VAR models. However, empirical studies of Granger causality are often based on bivariate models such as those in this study. See for example PuenteAjovin and Sanso-Navarro (2015) or Hu et al. (2015). 


\begin{tabular}{|l|l|l|l|}
\hline \multirow{3}{*}{ Croatia } & GDP_HR & $-8,398775^{*}(0)$ & Constant, Linear trend \\
\cline { 2 - 4 } & FDI_HR & $-5,332861^{*}(0)$ & Constant, Linear trend \\
\hline \multirow{3}{*}{ Latvia } & GDP_LV & $-3,157979^{*}(0)$ & - \\
\cline { 2 - 4 } & FDI_LV & $-4,882403^{*}(0)$ & Constant \\
\hline \multirow{3}{*}{ Hungary } & GDP_LT & $-6,203883^{*}(0)$ & Constant, Linear trend \\
\cline { 2 - 4 } & FDI_LT & $-6,008919^{*}(0)$ & Constant, Linear trend \\
\hline \multirow{2}{*}{ Poland } & GDP_HU & $-7,111317^{*}(0)$ & Constant, Linear trend \\
\cline { 2 - 4 } & FDI_HU & $-9,281262^{*}(0)$ & Constant, Linear trend \\
\hline \multirow{2}{*}{ Romania } & GDP_PL & $-4,100699^{*}(1)$ & Constant \\
\cline { 2 - 4 } & FDI_PL & $-5,588017^{*}(0)$ & Constant, Linear trend \\
\hline \multirow{2}{*}{ Slovenia } & GDP_RO & $-5,358165^{*}(0)$ & Constant, Linear trend \\
\cline { 2 - 4 } & FDI_RO & $-7,909013^{*}(0)$ & $-7,320067^{* *}(1)$ \\
\hline
\end{tabular}

Table 4-1 ADF test results in levels

Source: Author's calculations

Note: One (two) asterisk(s) denotes rejection of the null hypothesis at 1\% (5\%) significance level. Optimal lag number is determined by the Schwarz information criteria and given in brackets. Country abbreviations are included after the variables' names. BG stands for Bulgaria, CZ is Czech Republic, EE is Estonia, HR is Croatia, LV is Latvia, LT is Lithuania, HU is Hungary, PL is Poland, RO is Romania and SL is Slovenia. The same abbreviations are used in the remainder of the paper.

The test results indicate rejection of the null hypothesis on non-stationarity for all observed variables. That is, the observed series are stationary and do not contain a unit root.

\subsection{Granger causality}

Having tested the stationarity of the observed series, the analysis is continued through Granger causality tests. The basic principle of Granger causality analysis is to test the hypothesis that the past values of FDI help explain the current values of GDP and vice versa; whether past values of GDP can help explaining the current values of FDI.

However, prior to the analysis of causality it is necessary to determine the optimal number of lags in the model. The value of the optimal number of lags can be determined based on the information criteria of the 
model quality, AIC (Akaike), SC (Schwarz) and HQ (Hannan-Quinn). However, in this paper a minimum number of lags that fulfills the initial assumptions and the stability of the VAR model has been used. The optimal number of lags is given in Table 4-2, together with the Granger causality test results for all analyzed countries.

\begin{tabular}{|c|c|c|c|c|}
\hline Country & Null hypothesis & Lags & $\chi^{2}$ test & $p$ - value \\
\hline \multirow{2}{*}{ Bulgaria } & FDI_BG does not Granger cause GDP_BG & \multirow{2}{*}{2} & $8.069191^{* *}$ & 0.0177 \\
\hline & GDP_BG does not Granger cause FDI_BG & & 3.993522 & 0.1358 \\
\hline \multirow{2}{*}{ Czech Republic } & FDI_CZ does not Granger cause GDP_CZ & \multirow{2}{*}{2} & $11.17131^{*}$ & 0.0038 \\
\hline & GDP_CZ does not Granger cause FDI_CZ & & 0.102302 & 0.9501 \\
\hline \multirow{2}{*}{ Estonia } & FDI_EE does not Granger cause GDP_EE & \multirow{2}{*}{2} & 0.891039 & 0.6405 \\
\hline & GDP_EE does not Granger cause FDI_EE & & 1.246876 & 0.5361 \\
\hline \multirow{2}{*}{ Croatia } & FDI_HR does not Granger cause GDP_HR & \multirow{2}{*}{4} & $20.99203^{*}$ & 0.0003 \\
\hline & GDP_HR does not Granger cause FDI_HR & & 6.207932 & 0.1841 \\
\hline \multirow{2}{*}{ Latvia } & FDI_LV does not Granger cause GDP_LV & \multirow{2}{*}{4} & 4.802842 & 0.3081 \\
\hline & GDP_LV does not Granger cause FDI_LV & & $16.04082^{*}$ & 0.0030 \\
\hline \multirow{2}{*}{ Lithuania } & FDI_LT does not Granger cause GDP_LT & \multirow{2}{*}{3} & 3.030691 & 0.3869 \\
\hline & GDP_LT does not Granger cause FDI_LT & & 0.971102 & 0.8082 \\
\hline \multirow{2}{*}{ Hungary } & FDI_HU does not Granger cause GDP_HU & \multirow{2}{*}{1} & $9.632958^{*}$ & 0.0019 \\
\hline & GDP_HU does not Granger cause FDI_HU & & 0.018645 & 0.8914 \\
\hline \multirow{2}{*}{ Poland } & FDI_PL does not Granger cause GDP_PL & \multirow{2}{*}{2} & 4.566899 & 0.1019 \\
\hline & GDP_PL does not Granger cause FDI_PL & & 0.518641 & 0.7716 \\
\hline \multirow{2}{*}{ Romania } & FDI_RO does not Granger cause GDP_RO & \multirow{2}{*}{2} & $5.453748^{* * *}$ & 0.0654 \\
\hline & GDP_RO does not Granger cause FDI_RO & & 1.332003 & 0.5138 \\
\hline \multirow{2}{*}{ Slovenia } & FDI_SL does not Granger cause GDP_SL & \multirow{2}{*}{1} & 0.865337 & 0.3522 \\
\hline & GDP_SL does not Granger cause FDI_SL & & $5.136586^{* *}$ & 0.0234 \\
\hline
\end{tabular}

Table 4-2 Granger causality test results

Source: Author's calculations

Note: ${ }^{* * *}$ and ${ }^{* * *}$ denotes rejection of the null hypothesis at $1 \%, 5 \%$ and $10 \%$ significance level. 
Results of the Granger causality test show that FDI causes GDP in the Granger's sense in the model for Bulgaria, the Czech Republic, Croatia, Hungary and Romania. On the other hand, GDP causes FDI in the Granger's sense in the model for Latvia and Slovenia, while in other models there is no causal link between the observed variables.

\subsection{VAR model}

Finally, the relationship between the FDI and GDP growth rates will be analyzed using the VAR model. In any VAR analysis, the estimated parameters themselves are not so important. The same information, but presented in a form suitable for interpretation and conclusions, are given by the results of the innovation analysis consisting of the variance decomposition analysis and the impulse response functions.

\subsubsection{Variance decomposition}

The results of the variance decomposition analysis for the prognostic period of 16 quarters is presented in Table 4-3. However, in order to conduct the variance decomposition, first the variance-covariance matrix of VAR residuals has to be orthogonalized. Cholesky factorization is selected, presupposing a certain order of variables in the model. It is known that the order of variables can affect the results of the analysis. Ordinarily, a variable that does not affect other variables is positioned the last. Variables' ordering in Cholesky factorization is determined based on the results of the Granger causality test.

\begin{tabular}{|l|l|l|l|l|}
\hline \multirow{2}{*}{ Variance period } & \multicolumn{2}{|l|}{ Variance decomposition of FDI_BG } & \multicolumn{2}{l|}{ Variance decomposition of GDP_BG } \\
\cline { 2 - 5 } & FDI_BG & GDP_BG & FDI_BG & GDP_BG \\
\hline 1 & 100 & 0 & 0,64 & 99,36 \\
\hline 4 & 88,78 & 11,22 & 17,99 & 82,01 \\
\hline 8 & 84,70 & 15,30 & 21,01 & 78,99 \\
\hline 16 & 83,62 & 16,38 & 22,01 & 77,99 \\
\hline
\end{tabular}

Table 4-3 Variance decomposition of FDI_BG and GDP_BG

Source: Author's calculations

It is noted that FDI_BG fully explains the variance of its prognostic error in the first future period. After four years this percentage decreases to $83.62 \%$. On the other hand, GDP_BG explains $99.36 \%$ of the variance of its prognostic error in the following period. After four years this percentage decreases and stabilizes at the level of $77.99 \%$. 


\begin{tabular}{|l|l|l|l|l|}
\hline \multirow{2}{*}{ Variance period } & \multicolumn{2}{|l|}{ Variance decomposition of FDI_CZ } & \multicolumn{2}{l|}{ Variance decomposition GDP_CZ } \\
\cline { 2 - 5 } & FDI_CZ & GDP_CZ & FDI_CZ & GDP_CZ \\
\hline 1 & 100 & 0 & 48,26613 & 51,73387 \\
\hline 4 & 99,74429 & 0,255707 & 67,35653 & 32,64347 \\
\hline 8 & 99,73344 & 0,266557 & 67,33877 & 32,66123 \\
\hline 16 & 99,73336 & 0,266639 & 67,33912 & 32,66088 \\
\hline
\end{tabular}

Table 4-4 Variance decomposition of FDI_CZ and GDP_CZ

\section{Source: Author's calculations}

FDI_CZ fully explains the variance of its prognostic error in the first future quarter. After four years this percentage slightly decreases to $99.73 \%$. Therefore, GDP_CZ has almost no influence in explaining the prognostic error variations of FDI_CZ. On the other hand, FDI_CZ largely explains the variations of GDP_CZ. This share is $48.27 \%$ in the coming period, after which the percentage increases to $67.34 \%$ and, as such, remains virtually unchanged.

\begin{tabular}{|l|l|l|l|l|}
\hline \multirow{2}{*}{ Variance period } & \multicolumn{2}{|l|}{ Variance decomposition of FDI_EE } & \multicolumn{2}{l|}{ Variance decomposition of GDP_EE } \\
\cline { 2 - 5 } & FDI_EE & GDP_EE & FDI_EE & GDP_EE \\
\hline 1 & 100 & 0 & 0,01 & 99,99 \\
\hline 4 & 97,53 & 2,47 & 1,64 & 98,36 \\
\hline 8 & 96,47 & 3,53 & 2,01 & 97,99 \\
\hline 16 & 96,31 & 3,69 & 2,07 & 97,93 \\
\hline
\end{tabular}

Table 4-5 Variance decomposition of FDI_EE and GDP_EE

Source: Author's calculations

Variance decomposition of FDI_EE shows that the variable itself explains $100 \%$ of the variance of its prognostic error in the first future quarter. After four years this percentage slightly decreases to $96.31 \%$. Also, GDP_EE almost entirely explains the variance of its own prognostic error in the future period. After four years this percentage is still high and amounts to $97.93 \%$. 


\begin{tabular}{|l|l|l|l|l|}
\hline \multirow{2}{*}{ Variance period } & \multicolumn{2}{|l|}{ Variance decomposition of FDI_HR } & \multicolumn{2}{l|}{ Variance decomposition of GDP_HR } \\
\cline { 2 - 5 } & FDI_HR & GDP_HR & FDI_HR & GDP_HR \\
\hline 1 & 100 & 0 & 2,95 & 97,05 \\
\hline 4 & 93,96 & 6,04 & 22,52 & 77,48 \\
\hline 8 & 92,62 & 7,38 & 39,55 & 60,45 \\
\hline 16 & 92,60 & 7,40 & 40,43 & 59,57 \\
\hline
\end{tabular}

Table 4-6 Variance decomposition of FDI_HR and GDP_HR

Source: Author's calculations

FDI_HR fully explains the variance of its own prognostic error in the first future period. After four years this percentage slightly decreases to $92.60 \%$. On the other hand, GDP_HR explains $97.05 \%$ of the variance of its own prognostic error in the following period. After four years, the percentage drops significantly and amounts to $59.57 \%$, while the rest is explained by the movement of FDI_HR

\begin{tabular}{|l|l|l|l|l|}
\hline \multirow{2}{*}{ Variance period } & \multicolumn{2}{|l|}{ Variance decomposition of FDI_LV } & \multicolumn{2}{l|}{ Variance decomposition of GDP_LV } \\
\cline { 2 - 5 } & FDI_LV & GDP_LV & FDI_LV & GDP_LV \\
\hline 1 & 93,41 & 6,59 & 0 & 100 \\
\hline 4 & 64,59 & 35,41 & 8,78 & 91,22 \\
\hline 8 & 63,56 & 36,44 & 10,35 & 89,65 \\
\hline 16 & 63,58 & 36,42 & 10,54 & 89,46 \\
\hline
\end{tabular}

Table 4-7 Variance decomposition of FDI_LV and GDP_LV

Source: Author's calculations

It is noted that FDI_LV explains $93.41 \%$ of the variance of its own prognostic error in the first future quarter. After four years, this percentage decreases significantly and amounts to $63.58 \%$. Therefore, GDP_LV significantly participates in explaining the prognostic error variations of FDI_LV. On the other hand, GDP_LV fully explains the variance of its prognostic error in the following period. After four years this percentage slightly decreases to $89.46 \%$. 


\begin{tabular}{|l|l|l|l|l|}
\hline \multirow{2}{*}{ Variance period } & \multicolumn{2}{|l|}{ Variance decomposition of FDI_LT } & \multicolumn{2}{l|}{ Variance decomposition of GDP_LT } \\
\cline { 2 - 5 } & FDI_LT & GDP_LT & FDI_LT & GDP_LT \\
\hline 1 & 100 & 0 & 0,58 & 99,42 \\
\hline 4 & 98,80 & 1,20 & 7,04 & 92,96 \\
\hline 8 & 98,02 & 1,98 & 8,41 & 91,59 \\
\hline 16 & 97,99 & 2,01 & 8,47 & 91,53 \\
\hline
\end{tabular}

Table 4-8 Variance decomposition of FDI_LT and GDP_LT

Source: Author's calculations

Variance decomposition of FDI_LT shows that the variable itself explains $100 \%$ of the variance of its prognostic error in the first future quarter. After four years this percentage slightly decreases to $97.99 \%$. Also, GDP_LT almost entirely explains the variance of its own prognostic error in the following period. After four years, this percentage is still high and amounts to $91.53 \%$.

\begin{tabular}{|l|l|l|l|l|}
\hline \multirow{2}{*}{ Variance period } & \multicolumn{2}{|l|}{ Variance decomposition of FDI_HU } & \multicolumn{2}{l|}{ Variance decomposition of GDP_HU } \\
\cline { 2 - 5 } & FDI_HU & GDP_HU & FDI_HU & GDP_HU \\
\hline 1 & 100 & 0 & 8,90 & 91,10 \\
\hline 4 & 99,98 & 0,02 & 22,76 & 77,24 \\
\hline 8 & 99,98 & 0,02 & 22,76 & 77,24 \\
\hline 16 & 99,98 & 0,02 & 22,76 & 77,24 \\
\hline
\end{tabular}

Table 4-9 Variance decomposition of FDI_HU and GDP_HU

Source: Author's calculations

FDI_HU explains $100 \%$ of the variance of its own prognostic error in the coming period and this percentage remains virtually unchanged during the observed period. On the other hand, GDP_HU explains $91.10 \%$ of the variance of its prognostic error in the following period. After four years, the percentage drops significantly and amounts to $77.24 \%$, while the rest is explained by the movement of FDI_HU. 


\begin{tabular}{|l|l|l|l|l|}
\hline \multirow{2}{*}{ Variance period } & \multicolumn{2}{|l|}{ Variance decomposition of FDI_PL } & \multicolumn{2}{l|}{ Variance decomposition of GDP_PL } \\
\cline { 2 - 5 } & FDI_PL & GDP_PL & FDI_PL & GDP_PL \\
\hline 1 & 100 & 0 & 76,67 & 23,33 \\
\hline 4 & 99,49 & 0,51 & 84,63 & 15,37 \\
\hline 8 & 99,48 & 0,52 & 84,71 & 15,29 \\
\hline 16 & 99,48 & 0,52 & 84,71 & 15,29 \\
\hline
\end{tabular}

Table 4-10 Variance decomposition of FDI_PL and GDP_PL

Source: Author's calculations

It is noted that FDI_PL fully explains the variance of its prognostic error in the following period. After four years, that percentage remains almost unchanged. On the other hand, FDI_PL explains $76.67 \%$ of the variance of the prognostic error of GDP_PL. After four years this percentage increases to $84.71 \%$.

\begin{tabular}{|l|l|l|l|l|}
\hline \multirow{2}{*}{ Variance period } & \multicolumn{2}{|l|}{ Variance decomposition of FDI_RO } & \multicolumn{2}{l|}{ Variance decomposition of GDP_RO } \\
\cline { 2 - 5 } & FDI_RO & GDP_RO & FDI_RO & GDP_RO \\
\hline 1 & 100 & 0 & 21,80 & 78,20 \\
\hline 4 & 96,97 & 3,03 & 34,89 & 65,11 \\
\hline 8 & 96,79 & 3,21 & 35,67 & 64,33 \\
\hline 16 & 96,79 & 3,21 & 35,70 & 64,30 \\
\hline
\end{tabular}

Table 4-11 Variance decomposition of FDI_RO and GDP_RO

Source: Author's calculations

FDI_RO explains $100 \%$ of the variance of its prognostic error in the following period. After four years this percentage slightly decreases to $96.79 \%$. On the other hand, GDP_RO explains $78.20 \%$ of the variance of its prognostic error in the following period. After four years, the percentage drops significantly and amounts to $64.30 \%$, while the rest is explained by the movement of FDI_RO. 


\begin{tabular}{|l|l|l|l|l|}
\hline \multirow{2}{*}{ Variance period } & \multicolumn{2}{|l|}{ Variance decomposition of FDI_SL } & \multicolumn{2}{l|}{ Variance decomposition of GDP_SL } \\
\cline { 2 - 5 } & FDI_SL & GDP_SL & FDI_SL & GDP_SL \\
\hline 1 & 88,20 & 11,80 & 0 & 100 \\
\hline 4 & 77,85 & 22,15 & 1,63 & 98,37 \\
\hline 8 & 77,84 & 22,16 & 1,63 & 98,37 \\
\hline 16 & 77,84 & 22,16 & 1,63 & 98,37 \\
\hline
\end{tabular}

Table 4-12 Variance decomposition of FDI_SL and GDP_SL

Source: Author's calculations

Variance decomposition of FDI_SL shows that the variable itself explains $88.20 \%$ of the variance of its prognostic error in the first future quarter. After four years, the percentage decreases and amounts to $77.84 \%$, while the rest is explained by the movement of GDP_SL. On the other hand, GDP_SL almost entirely explains the variance of its own prognostic error during the entire prognostic period.

The conducted analysis leads to the conclusion that the variance decomposition gives the same information about the cause-effect relationship between FDI and GDP in the observed countries as the Granger causality test.

\subsubsection{Impulse responses}

The following part of the analysis is devoted to the reaction of certain variables on the unit shock in other variables.

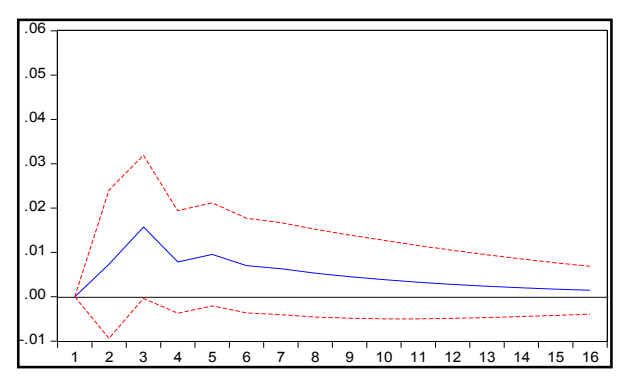

Figure 4-1 Response of FDI_BG to GDP_BG Source: Author's calculations

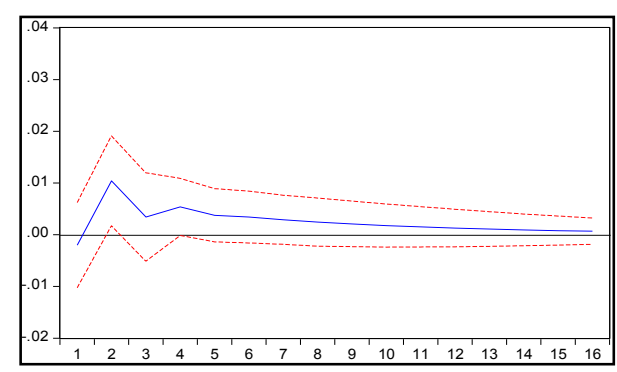

Figure 4-2 Response of FDI_BG to GDP_BG Source: Author's calculations

It is noted that an increase of GDP_BG of one standard deviation would affect the increase of FDI_BG during the first three quarters, after which the effect begins to fade away. On the other hand, the impact of FDI_BG shock on GDP_BG is the most pronounced in the second quarter. 

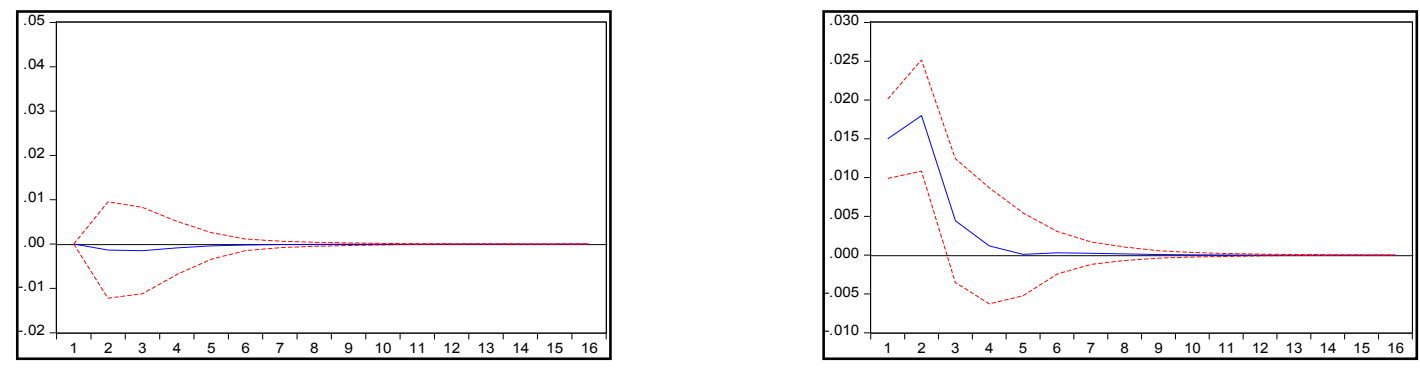

Figure 4-3 Response of FDI_BG to GDP_BG

Source: Author's calculations

Figure 4-4 Response of FDI_BG to GDP_BG

Source: Author's calculations

Furthermore, the shock of one standard deviation in GDP_CZ has a slightly negative, almost neutral effect on FDI_CZ. On the other hand, there is a positive impact of shock in FDI_CZ on GDP_CZ during the first two quarters, after which it starts to disappear.

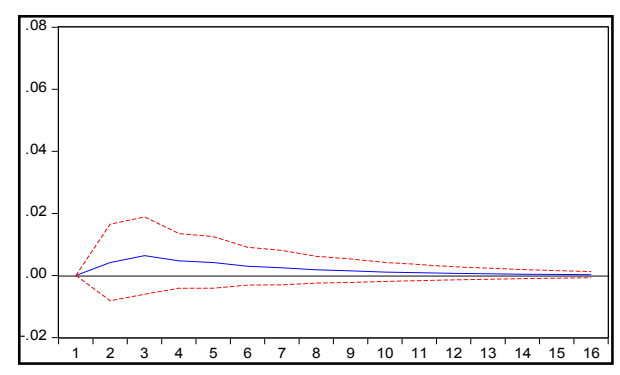

Figure 4-5 Response of FDI_BG to GDP_BG

Source: Author's calculations

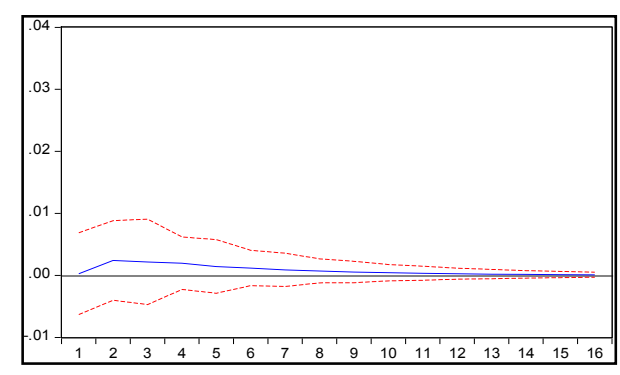

Figure 4-6 Response of FDI_BG to GDP_BG

Source: Author's calculations

An increase of GDP_EE by one standard deviation has a slight positive effect on FDI_EE. Also, a shock in FDI_EE has a slight positive effect on GDP_EE.

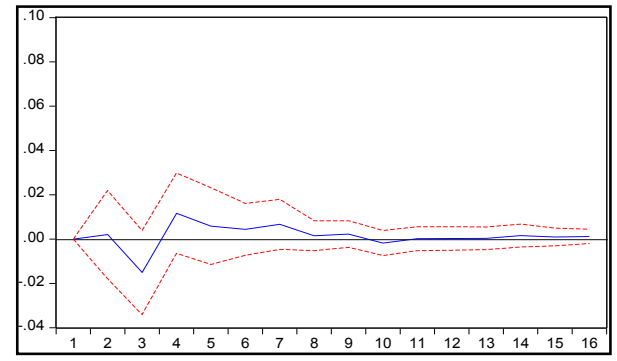

Figure 4-7 Response of FDI_BG to GDP_BG

Source: Author's calculations

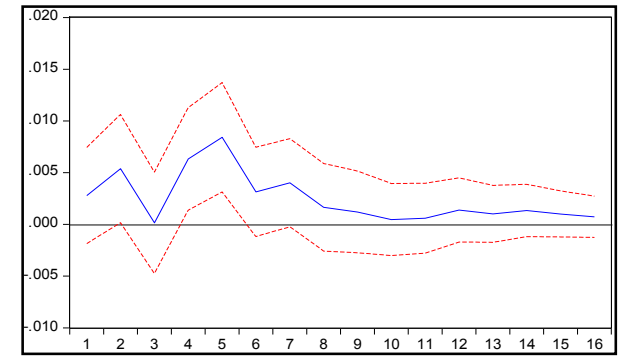

Figure 4-8 Response of FDI_BG to GDP_BG

Source: Author's calculations

It is observed that the shock of one standard deviation in GDP_HR has a slight positive, almost neutral effect on FDI_HR. On the other hand, there is a positive impact of shock in FDI_HR on GDP_HR during the first two quarters, after which it starts to disappear. 


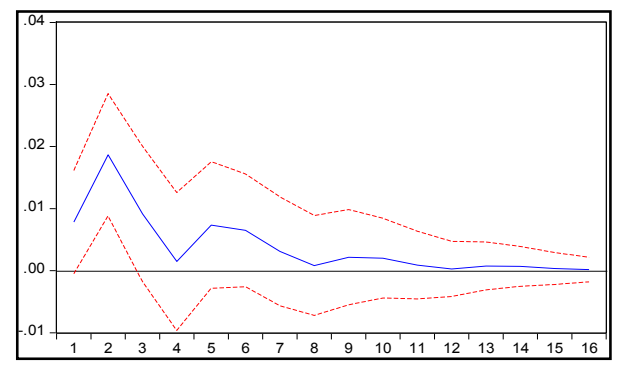

Figure 4-9 Response of FDI_BG to GDP_BG

Source: Author's calculations

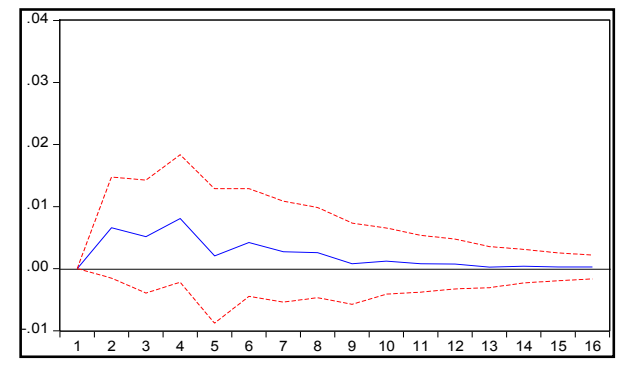

Figure 4-10 Response of FDI_BG to GDP_BG

Source: Author's calculations

The shock of one standard deviation in GDP_LV has a positive effect on FDI_LV in the first two quarters, after which the effect begins to fade away. Furthermore, there is a positive effect of shock in FDI_LV on GDP_LV and it is the most pronounced in the fourth quarter.

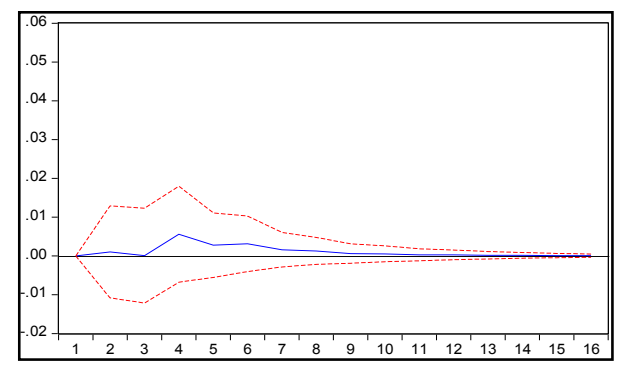

Figure 4-11 Response of FDI_BG to GDP_BG

Source: Author's calculations

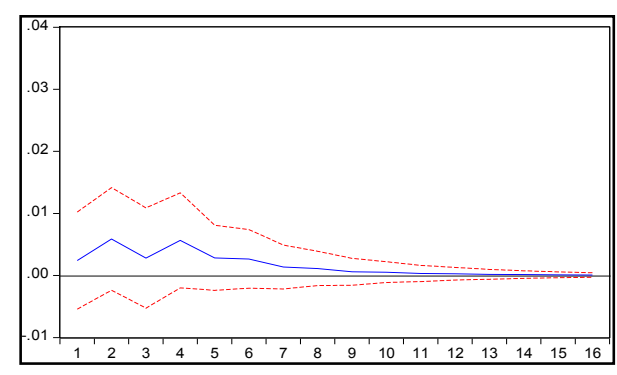

Figure 4-12 Response of FDI_BG to GDP_BG

Source: Author's calculations

An increase of GDP_LT by one standard deviation has a slight positive, almost neutral effect on FDI_LT. On the other hand, there is a positive impact of shock in FDI_LT on GDP_LT during the first four quarters, after which it starts to disappear.
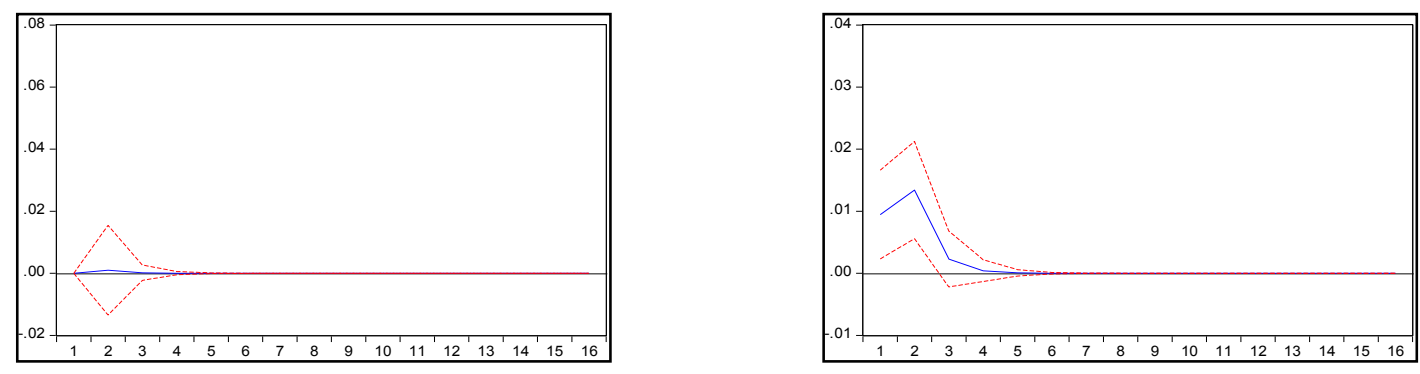

Figure 4-13 Response of FDI_BG to GDP_BG Source: Author's calculations
Figure 4-14 Response of FDI_BG to GDP_BG

Source: Author's calculations 
The shock of one standard deviation in GDP_HU has an almost neutral effect on FDI_HU. On the other hand, there is a positive impact of shock in FDI_HU on GDP_HU during the first two quarters, after which it starts to disappear.

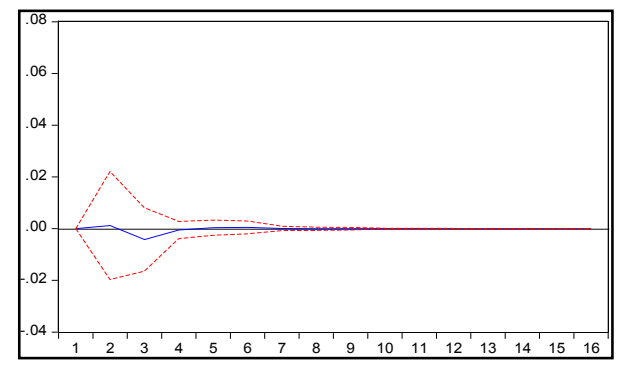

Figure 4-15 Response of FDI_BG to GDP_BG Source: Author's calculations

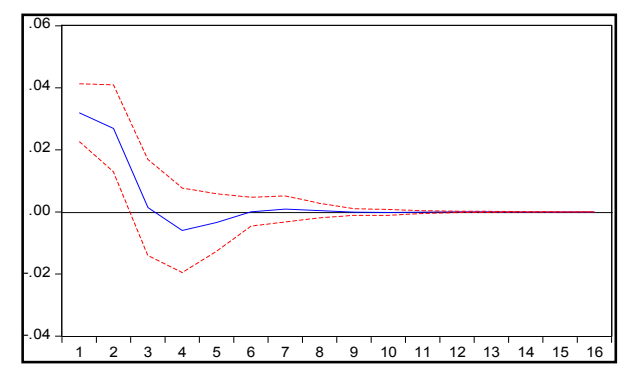

Figure 4-16 Response of FDI_BG to GDP_BG Source: Author's calculations

The shock of one standard deviation in GDP_PL has an almost neutral effect on FDI_PL. On the other hand, there is a positive impact of shock in FDI_PL on GDP_PL during the first two quarters, after which it starts to disappear.
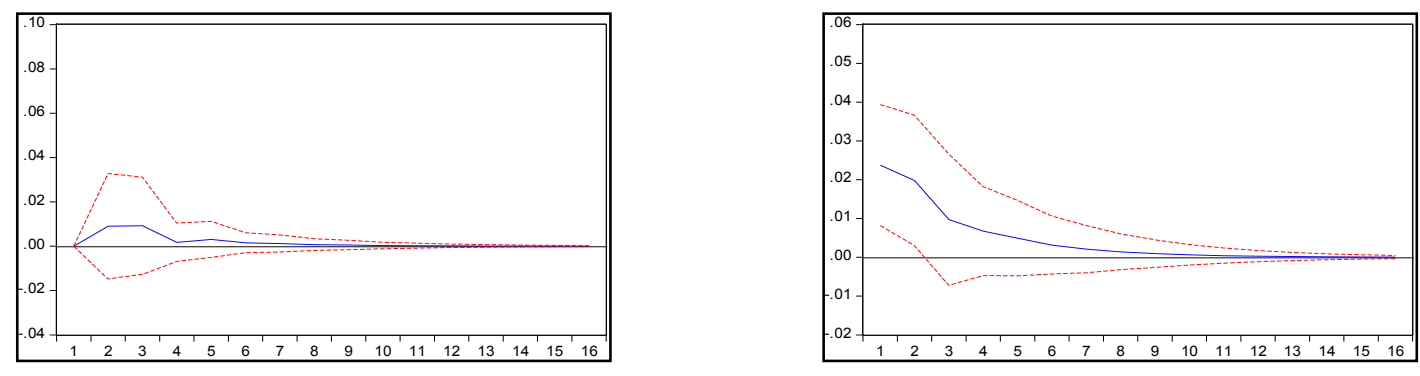

Figure 4-17 Response of FDI_BG to GDP_BG

Source: Author's calculations
Figure 4-18 Response of FDI_BG to GDP_BG

Source: Author's calculations

An increase of GDP_RO by one standard deviation has a slight positive effect on FDI_RO during the first three quarters. Also, there is a positive impact of shock in FDI_RO on GDP_RO during the first two quarters, after which it starts to disappear.

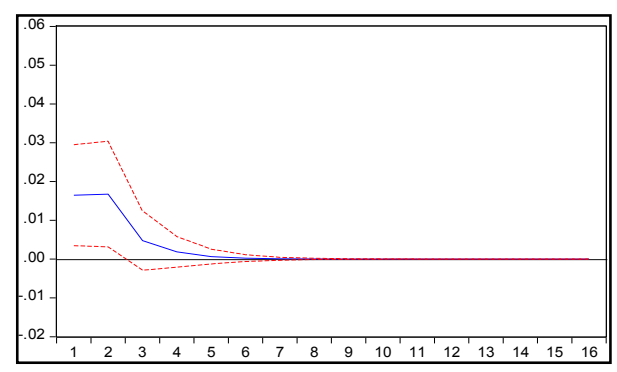

Figure 4-20 Response of FDI_BG to GDP_BG Source: Author's calculations

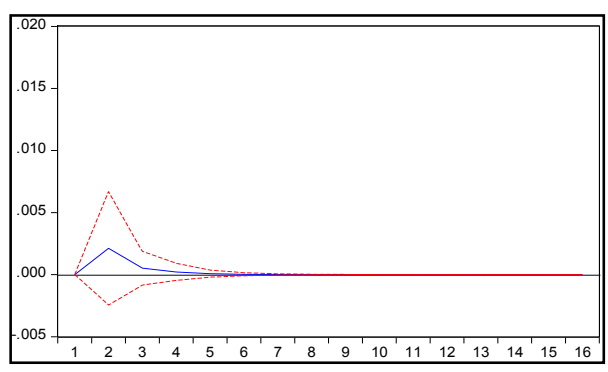

Figure 4-21 Response of FDI_BG to GDP_BG Source: Author's calculations 
The shock of one standard deviation in GDP_SL has a positive effect on FDI_SL in the first two quarters, after which the effect begins to fade away. Also, there is a positive impact of shock in FDI_SL on GDP_SL during the second quarter, after which it starts to disappear.

Finally, the analysis of adequacy of the VAR model was also conducted. An overview of diagnostic test results is given in Table 4-13.

\begin{tabular}{|l|l|l|l|}
\hline Country & LM (12) & Jarque - Bera & White \\
\hline Bulgaria & 0,97 & 0,13 & 0,58 \\
\hline Czech Republic & 0,31 & 0,14 & 0,24 \\
\hline Estonia & 0,82 & 0,00 & 0,14 \\
\hline Croatia & 0,77 & 0,57 & 0,33 \\
\hline Latvia & 0,49 & 0,06 & 0,36 \\
\hline Lithuania & 0,98 & 0,00 & 0,08 \\
\hline Hungary & 0,62 & 0,00 & 0,00 \\
\hline Poland & 0,15 & 0,09 & 0,71 \\
\hline Romania & 0,32 & 0,00 & 0,14 \\
\hline Slovenia & 0,48 & 0,00 & 0,87 \\
\hline
\end{tabular}

Table 4-13 Diagnostic test results overview for VAR model ( $p$-value)

Source: Author's calculations

Diagnostic checking concludes that the LM test for autocorrelation gives satisfactory results in all models. The null hypothesis of no autocorrelation between the $12^{\text {th }}$ order cannot be rejected at any conventional significance level. Also, in most models, the White test cannot reject the null hypothesis of homoskedasticity of the residual variance. This assumption is violated only in the model for Hungary. On the other hand, in most of the analyzed models the assumption of normal distribution of residuals is violated, as the JarqueBera test rejects the null hypothesis of normal distribution of residuals at all conventional levels of significance. This assumption was, at all levels of significance, satisfied in the model for Bulgaria, the Czech Republic and Croatia. Stability of the observed VAR models was also examined. It was found that all the roots of the characteristic polynomials are inside the unit circle, hence the models are stable. 


\section{Discussion}

Empirical analysis has led to the conclusion that in most countries FDI is an important determinant of economic growth. This is especially true in Poland, Czech Republic and Hungary, which have, to a large extent, taken advantage of joining the European Union. By creating a favorable investment climate, including the relatively low cost of labor, they have attracted a large number of investors from developed countries of the European Union, who brought with them new technologies, management knowledge and skills. Increased efficiency of production and operation of all the sectors have had a positive impact on economic growth. These results concur with the common belief that FDI has a positive effect on GDP growth and are in accordance with the recent literature on the subject of FDI-GDP growth relation (Blomström, Lipsey \& Zejan, 1992; Bačić, Račić \& Ahec - Šonje, 2004; Asteriou, Dassiou \& Glycopantis, 2005; etc.)

Also, it is noted that in Croatia, FDI is an important factor that can greatly promote higher rates of economic growth. However, investments in Croatia are in decline due to the lack of industrial development plan, high labor costs, high administrative barriers and other obstacles in comparison with other transition countries. Therefore, if Croatia wants to encourage the growth of the economy, then it has to create a stable business environment that will attract foreign as well as domestic investors. Results show that in some countries, such as Latvia and Slovenia, economic growth plays an important role in attracting the FDI. Foreign investors are prone to come countries with a stable macroeconomic environment, which implies positive growth rates of GDP. This is in accordance with the results provided by Franc (2008), indicating that FDI inflow is determined by lower labor cost, GDP growth rate etc. It is important to note that FDI-GDP growth relation is surely determined by other variables which are not included in this analysis thus, opening room for further research. Competitiveness, for example, surely affects GDP growth through foreign trade which, in turn, directly affects FDI inflows and thus, affects FDI-GDP growth relationship. Competitiveness is further determined by factors such as credit rating, tax evasion, access to capital markets, SMEs, labor regulation flexibility, finance and banking regulation (Mačkić, Škrabić Perić \& Sorić, 2014).

\section{Conclusion}

Every country seeks to encourage its economic growth yet, it is impossible to do so without an important factor - capital. Therefore, a country lacking in savings has to resort to importing capital. FDI represents the most significant and propulsive way of international capital flow and it is a prerequisite of technological and economic development for many countries (especially the transition ones). Various empirical studies, which also include non-transition countries provide different results but the common conclusion is that FDI, by itself, does not necessarily have an independent and positive impact on GDP growth as it depends on other economic and social conditions as human capital, financial system development, etc. Empirical analysis done in this paper has led to the conclusion that FDI has a positive impact on GDP growth rate in most of the analyzed countries, especially, in Poland, Czech Republic and Hungary. These countries have attracted a 
significant amount of FDI through which encouraged the growth of their economies. The research has also shown that there is reverse link; i.e. GDP growth rates are important in attracting FDI.

\section{References}

- Asteriou, D., Dassiou, X. \& Glycopantis, D. (2005). FDI and Growth: Evidence from a Panel of European Transition Countries. Spoudai, 55(1), 9-30.

- Bačić, K., Račić, D. \& Ahec - Šonje, A. (2004). The effects of FDI on recipient countries in Central and Eastern Europe. Privredna kretanja i ekonomska politika, 14(100), 59-96.

- Blomström, M., Lipsey, R. \& Zejan, M. (1992). What Explains Developing Country Growth?. Working Paper [4132], NBER.

- Borensztein, E., De Gregorio, J. \& Lee, J.-W. (1995). How Does Foreign Direct Investment Affect Economic Growth?. Working Paper [5057], NBER.

- Curwin, K.D. \& Mahutga, M.C. (2014). Foreign Direct Investment and Economic Growth: New Evidence from Post-Socialist Transition Countries. Social Forces, 92(3), 1159-1187.

- Dickey, D. A. \& Fuller, W. A. (1981). Likelihood Ratio Statistics for Autoregressive Time Series With a Unit Root. Econometrica, 49(4), 1057-1072.

- Franc, S. (2008). Komparativna analiza determinanti inozemnih izravnih ulaganja u Hrvatsku i odabrane zemlje EU. Zbornik Ekonomskog fakulteta u Zagrebu, 6(1), 29-44.

- Granger, C. W. J. (1969). Investigating Causal Relations by Econometric Models and Cross-Spectral Methods. Econometrica, 37(3), 424 - 438.

- Hu, Y., Xiao, J., Deng, Y., Xiao, Y. \& Wang, S.Y. (2015). Domestic air passenger traffic and economic growth in China: Evidence from heterogeneous panel models. Journal of Air Transport Management, 42: 95-100.

- Katircioglu, S. (2009). Foreign Direct Investment and Economic Growth in Turkey: An Empirical Investigation by the Bounds Test for Co - integration and Causality Tests. Ekonomska istraživanja, 22(3), 1-9.

- Kersan-Škabić, I. \& Zubin, C. (2009). Utjecaj izravnih inozemnih ulaganja na rast BDP, na zaposlenost i na izvoz u Hrvatskoj. Ekonomski pregled, 60(3-4), 119 - 151.

- Mačkić, V., Škrabić Perić, B. \& Sorić, P. (2014). Systemic competitiveness of postsocialist and capitalist economies: a broader look at the competitiveness debate. Post-Communist Economies, 26(4), 477-497.

- Mencinger, J. (2003). Does Foreign Direct Investment Always Enhance Economic Growth?. Kyklos, International Review for Social Sciences, 56(4), 491 - 508.

- Neuhaus, M. (2005). The Impact of FDI on Economic Growth. An Analysis for the Transition Countries of Central and Eastern Europe. Physica-Verlag, Heidelberg

- Puente-Ajovin, M. \& Sanso-Navarro, M. (2015). Granger causality between debt and growth: Evidence from OECD countries. International Review of Economics\&Finance, 35: 66-77. 